\title{
Strategi Pemanfaatan Media Sosial untuk Pemasaran Digital oleh Petani Porang di Kabupaten Wonogiri Masa Pandemi COVID-19
}

\author{
Muhammad Ivan Rizki ${ }^{1 *}$, Alfian Khamal Mustafa ${ }^{1}$, Eullia Tri Mukti Hezak ${ }^{1}$, \\ Puspita Annisa Utami ${ }^{1}$ \\ ${ }^{1}$ Program Studi Penyuluhan dan Komunikasi Pertanian, Fakultas Pertanian, \\ Universitas Sebelas Maret \\ *Corresponding author: muhammadivanrizki@gmail.com
}

\begin{abstract}
Abstrak
Media sosial saat ini sudah menjadi kebutuhan hidup yang tidak bisa terlepaskan dari setiap aktivitas manusia. Pemasaran dengan memanfaatkan media sosial saat ini menjadi kegemaran masyarakat dari berbagai kalangan, termasuk dalam pemasaran hasil produk pertanian. Penelitian ini bertujuan untuk meninjau tingkat efektivitas dan manfaat penggunaan media sosial sebagai strategi pemasaran digital porang oleh petani milenial di Wonogiri. Penelitian ini menggunakan deskriptif kualitatif yang diamati pada studi kasus tertentu untuk diamati dan dianalisis secara cermat sampai tuntas. Lokasi penelitian ditentukan secara sengaja (purposive) lokasi yang dipilih yaitu Kabupaten Wonogiri. Pemilihan informan dilakukan secara sengaja (purposive) dan menggunakan teknik snowball sampling untuk menemukan informan kunci yang memiliki banyak informasi. Informan yang dipilih adalah Petani Porang di Kabupaten Wonogiri dan Kepala BPP Kabupaten Wonogiri. Teknik pemasaran yang tepat untuk menjual dan mempromosikan produk hasil panen tanaman porang tersebut di saat pandemi ini adalah dengan teknik pemasaran digital. Bentuk pemasaran digital yang digunakan petani di Kabupaten Wonogiri melalui penggunaan media sosial untuk memasarkan hasil panen porangnya. Strategi content marketing yang diterapkan para petani porang milenial untuk menarik pelanggan yaitu dengan menggunakan piramida konten. Lelang online sebagai strategi lain yang dilakukan oleh petani porang milenial Wonogiri. Bentuk pemasaran digital yang digunakan oleh petani dalam pemasaran produk ini adalah penggunaan media sosial sebagai wadah dari pemasaran produk hasil panen tanaman porang di Kabupaten Wonogiri, adanya penggunaan media sosial oleh petani porang milenial di Kabupaten Wonogiri ini dengan mudah mempertemukan pembeli atau pengepul, sehingga lebih efektif dan efisien diterapkan dalam pemasaran terutama di masa pandemi COVID-19.
\end{abstract}

Kata kunci: Konten, Media sosial, Petani milenial, Pemasaran digital, Porang

\section{Abstract}

Social media has now become a necessity of life that cannot be separated from all human activity. Marketing using social media is currently a hobby of people from a variety of backgrounds, including agricultural marketing. This study aims to examine the level of effectiveness and benefits of using social media as a porang digital marketing strategy by millennial farmers in Wonogiri. This research uses qualitative descriptions that are observed in some case studies to be carefully observed and analyzed through to completion. The location of the study was intentionally (purposive) determined in the location of Wonogiri Regency. The selection of informants was made on purpose and used a snowball sampling technique to find key informants who had a lot of information. The selected informants were the farmers of Porang in the regency of Wonogiri and the head of the BPP in the regency of Wonogiri. The right marketing technique to sell and promote porang culture products during this pandemic are digital marketing techniques. The form of digital marketing used by farmers in Wonogiri Regency is to use social media to market their porang harvest. The content marketing strategy applied by millennial porang farmers to attract customers 
Prosiding Seminar Nasional Pembangunan dan Pendidikan Vokasi Pertanian

Politeknik Pembangunan Pertanian Manokwari, 31 Juli 2021

e ISSN : 2774-1982

DOI : https://doi.org/10.47687/snppvp.v2i1.175

is to use a content pyramid. Online auctions are another strategy implemented by the millennial porang farmers of Wonogiri. The form of digital marketing used by farmers to market this product is the use of social media as a forum for marketing the products of porang crops in Wonogiri Regency. It is applied more effectively and efficiently in marketing, especially during the COVID19 pandemic.

Keywords: Content, Digital Marketing, Milenial Farmer, Porang, Social Media

\section{PENDAHULUAN}

Dampak pandemi COVID-19 yang telah menyebar sejak awal tahun 2020 hingga saat ini belum menunjukkan penurunan, bahkan dapat dikatakan semakin memburuk. Tercatat pada 5 Juli 2021, secara global sebanyak 183.560.151 kasus COVID-19 telah dikonfirmasi, termasuk juga 3.978.581 kematian dilaporkan (WHO Coronavirus (COVID19) Dashboard-WHO, 2021). Tidak hanya bidang kesehatan, bidang perekonomian pun juga turut terkena imbas dan menjadi krisis global lain yang perlu diperhatikan. Terjadi penurunan aktivitas dalam hal bisnis maupun harian akibat kebijakan pembatasan masyarakat. Hal ini menyebabkan penurunan daya beli yang tidak seimbang dengan suplai penawaran juga menjadi alasan mengapa pemutusan hubungan kerja kerap terjadi. Rentetan peristiwa ini menjadi alasan mengapa banyak perusahaan dan pelaku usaha di berbagai negara harus menutup unit usahanya (Adianto, 2020; Kraus, et al., 2020; McKibbin dan Fernando, 2020).

Pandemi ini juga terbukti menciptakan masyarakat marginal baru, diantaranya yaitu mereka yang bekerja di sektor informal dan mereka yang tidak memiliki akses terhadap internet dan teknologi (Eddyono et al., 2020). Menurut data BPS (2018), persentase tenaga kerja formal di Indonesia pada tahun 2018 mencapai 41,78\% yang berarti $58,22 \%$ tenaga kerja bekerja di sektor informal. Potensi pekerja yang akan kehilangan pendapatan mereka tentunya dapat dibayangkan dalam jumlah yang tidak sedikit. Selanjutnya, seperti yang kita ketahui bahwa peradaban manusia mulai memasuki era Society 5.0. Menurut Nastiti dan Abdu (2020), Society 5.0 dapat diartikan sebagai sebuah konsep masyarakat yang berpusat pada manusia dan berbasis teknologi. Mereka yang memiliki akses teknologi akan memiliki kelebihan dalam mendapatkan informasi, dan berlaku sebaliknya bagi mereka yang tidak memiliki kesempatan ini akan dirugikan.

Beruntungnya sektor pertanian tampil sebagai sektor yang mampu bertahan dalam krisis pandemi. Menurut data BPS year on year Triwulan I 2021, sektor pertanian mengalami pertumbuhan sebesar 2,95\% yang mana menjadi pertumbuhan PDB terbesar menurut lapangan usaha. Sayangnya, masih banyak petani yang menemui tantangan dan 
Prosiding Seminar Nasional Pembangunan dan Pendidikan Vokasi Pertanian

Politeknik Pembangunan Pertanian Manokwari, 31 Juli 2021

e ISSN : 2774-1982

DOI : https://doi.org/10.47687/snppvp.v2i1.175

goncangan yang diakibatkan pandemi. Tantangan tersebut seperti tingginya permintaan yang harus dipenuhi, kesanggupan untuk menjaga kualitas produk, jalur distribusi, dan banyak hal lain yang membutuhkan penyesuaian strategi yang dapat meminimalisir kontak langsung (Wulandani dan Anggraini, 2020). Sektor pertanian Kabupaten Wonogiri cukup maju didukung pula atas kepemilikan lahan pertanian yang luas. Tercatat penggunaan luas lahan pertanian bukan sawah terbesar Kabupaten Wonogiri adalah untuk tegal/kebun sebesar $87.762 \mathrm{ha}$, sedangkan penggunaan luas lahan pertanian bukan sawah yang terkecil adalah lahan sementara tidak diusahakan sebesar 167 ha. (BPS Wonogiri, 2019). Keunggulan luas lahan ini sangat potensial untuk berbagai macam komoditas tanam, salah satunya ialah porang (Amorphophallus Muelleri Blume). Menurut Rofik et al. (2017) tanaman porang adalah salah satu tanaman yang sudah lama dikenal oleh masyarakat sejak zaman pendudukan Jepang. Beberapa petani milenial di Kabupaten Wonogiri sendiri telah menggunakan media sosial sebagai sarana bentuk pemasaran digital komoditas tanam porang.

Beberapa penelitian yang berkaitan dengan penggunaan media sosial dalam strategi pemasaran di antara lain penelitian yang dilakukan Setiyorini et al. (2018) menghasilkan beberapa strategi prioritas dalam pemasaran produk UMKM Cindy Group yaitu memperluas jaringan pemasaran, mempertahankan mutu dan meningkatkan pelayanan penjualan, serta meningkatkan kerjasama dengan instansi terkait. Penelitian kedua dilakukan Siagian et al. (2020) bahwa semakin majunya perkembangan teknologi bahkan dengan adanya media sosial membuat masyarakat khusunya pengusaha dapat menjangkau calon pembeli dengan mudah. Penelitian ketiga dilakukan Rini dan Shihab (2018) menggunakan pendekatan kualitatif yang terdiri atas case study research dan action research, didapatkan berupa rumusan strategi media sosial dengan menerapkan kerangka teoritis, metodologi penelitian, dan kondisi sasaran.

Penelitian selanjutnya Feryanto dan Rosiana (2021) menujukkan petani yang adaptif dan menggunakan telepon selulernya untuk mendukung kegiatan usahataninya akan mampu membuka peluang pasar yang lebih luas, mendapatkan informasi lebih cepat dan mampu dalam jangka panjang mampu meningkatkan kesejahterannya. Terakhir, penelitian Trymastuty et al. (2020) menghasilkan pemanfaatan media sosial membantu petani dalam mempermudah pemasaran hasil pertanian serta meningkatkan nilai jual sehingga akan meningkatkan juga pendapatan petani. 
Prosiding Seminar Nasional Pembangunan dan Pendidikan Vokasi Pertanian

Politeknik Pembangunan Pertanian Manokwari, 31 Juli 2021

e ISSN : 2774-1982

DOI : https://doi.org/10.47687/snppvp.v2i1.175

Penelitian ini bertujuan untuk mengetahui strategi pemasaran porang yang diterapkan petani porang di Kabupaten Wonogiri, utamanya petani milenial dan guna mempelajari dampak dan manfaat yang dibawa oleh strategi pemasaran digital dalam penjualan komoditas porang di Kabupaten Wonogiri.

\section{METODE}

Metode yang digunakan dalam penelitian ini adalah deskriptif kualitatif yang diamati pada studi kasus tertentu untuk diamati dan dianalisis secara cermat sampai tuntas. Metode penelitian kualitatif adalah metode penelitian yang berdasarkan filsafat positivisme yang digunakan untuk meneliti pada kondisi alamiah, dimana peneliti sebagai instrumen kunci, teknik pengumpulan data dilakukan secara triangulasi, analisis data bersifat induktif, dan hasil penelitian lebih menekankan makna daripada generalisasi (Sugiyono, 2013). Lokasi penelitian ditentukan secara sengaja (purposive). Lokasi yang dipilih yaitu Kabupaten Wonogiri.

Pemilihan informan dilakukan secara sengaja (purposive) dan menggunakan teknik snowball sampling untuk menemukan informan kunci yang memiliki banyak informasi. Informan yang dipilih adalah Petani Porang di Kabupaten Wonogiri dan Kepala BPP Kabupaten Wonogiri. Key informan yang diwawancarai yaitu petani porang milenial Kabupaten Wonogiri. Peneliti melakukan observasi, wawancara (in-depth interview), dokumentasi, dan data sekunder melalui studi pustaka sebagai pengumpulan data penelitian. Analisis data kualitatif dilakukan secara interaktif. Menurut Sugiyono (2013) aktivitas yang dilakukan dalam analisis data kualitatif adalah secara interaktif dan terus menerus sampai tuntas dan datanya sudah jenuh. Aktivitas tersebut terdiri dari empat tahap yaitu pengumpulan data, reduksi data, sajian data, dan penarikan kesimpulan (Miles dan Huberman, 2007).

\section{HASIL DAN PEMBAHASAN}

Petani porang di Kabupaten Wonogiri khususnya petani milenial di tengah pandemi melakukan inovasi dalam pemasaran hasil panen tanaman porang. Teknik pemasaran yang tepat untuk menjual dan mempromosikan produk hasil panen tanaman porang tersebut di saat pandemi ini adalah dengan teknik pemasaran digital. Saat pandemi seperti ini teknik pemasaran digital memiliki peluang yang besar dalam memasarkan produk, selain adanya pembatasan aktivitas di masyarakat di sisi lain kebutuhan terhadap teknologi digital sudah mendarah daging dalam kehidupan setiap elemen masyarakat. Menurut Muljono (2018), 
Prosiding Seminar Nasional Pembangunan dan Pendidikan Vokasi Pertanian

Politeknik Pembangunan Pertanian Manokwari, 31 Juli 2021

e ISSN : 2774-1982

DOI : https://doi.org/10.47687/snppvp.v2i1.175

kebutuhan pemasaran digital yang menggunakan internet sebagai wadah untuk kegiatan pemasaran sampai saat ini sudah tidak terbendung lagi. Mulai dari perusahaan-perusahaan multinasional hingga perusahaan-perusahaan mikro berlomba-lomba untuk mendapatkan pelanggan melalui pemasaran digital. Hal tersebut mengakibatkan konsep pemasaran digital menjadi primadona bagi dunia pemasaran, hingga akhirnya melahirkan industri baru yang pelakunya dikenal sebagai digital marketer. Bentuk pemasaran digital yang digunakan oleh petani dalam pemasaran produk ini adalah penggunaan media sosial sebagai wadah dari pemasaran produk hasil panen tanaman porang di Kabupaten Wonogiri.

Penggunaan media sosial oleh petani milenial tanaman porang Kabupaten Wonogiri dinilai lebih efisien dan mampu menjangkau pasar lebih luas. Terlebih masa pandemi COVID-19 seperti ini para petani porang sulit untuk memasarkan hasil panen secara langsung di pasar, sehingga solusi menggunakan media sosial sebagai media pemasaran hasil panen porang merupakan pilihan yang sangat tepat. Menurut informan, dengan memakai media sosial lebih mudah dan juga praktis. Selain itu, dengan memakai media sosial dalam hal memasarkan hasil panen di masa pandemi dapat menghindari kontak fisik secara langsung. Adanya penerapan media sosial di lingkup petani milenial tidak hanya sebagai akses untuk memasarkan hasil panennya, tetapi juga digunakan untuk bertukar pengalaman atau berdiskusi dengan petani lainnya dengan grup yang dibuat. Perubahan yang dirasakan dari segi pemasaran sebelum dan sesudah menggunakan media sosial jauh berbeda. Sesudah memakai media sosial para petani dapat memantau harga pasar dan tidak lagi dipermainkan oleh pengepul. Selain itu, menggunakan media sosial dalam hal pemasaran hasil panen mewujudkan era revolusi industri 4.0 dan society 5.0.

Petani porang milenial menyesuaikan diri dalam menggunakan media sosial terlebih di masa pandemi. Bentuk pemasaran digital yang digunakan petani di Kabupaten Wonogiri melalui media sosial sebagai wadah dari pemasaran produk hasil panen porangnya memberi dampak yang signifikan untuk penjualan porang. Media sosial yang dijalankan tersebut berisi konten-konten yang berkaitan dengan produk porang yang dibudidayakan setiap petani. Pembuatan konten sebagai strategi pemasaran dinilai dapat menarik pelanggan untuk mengunjungi dan melakukan transaksi melalui media sosial yang dimiliki tersebut. Hasil observasi melalui wawancara dengan beberapa informan bahwa pengguna content marketing ini sangat membantu dalam meningkatkan daya jual produk porang yang mereka budidayakan terutama dalam mempromosikan produk terkait serta dalam mentransformasikan dengan para pelanggan. 
Prosiding Seminar Nasional Pembangunan dan Pendidikan Vokasi Pertanian Politeknik Pembangunan Pertanian Manokwari, 31 Juli 2021

e ISSN : 2774-1982

DOI : https://doi.org/10.47687/snppvp.v2i1.175

Strategi content marketing yang diterapkan para petani porang milenial untuk menarik pelanggan yaitu dengan menggunakan piramida konten. Piramida konten ini dibagi menjadi 3 tingkatan yaitu hero sebagai konten utama, hub sebagai konten penghubung, dan hygiene sebagai konten rutin. Ketiga tingkatan tersebut harus memiliki unsur produk dari proses budidaya porang petani.

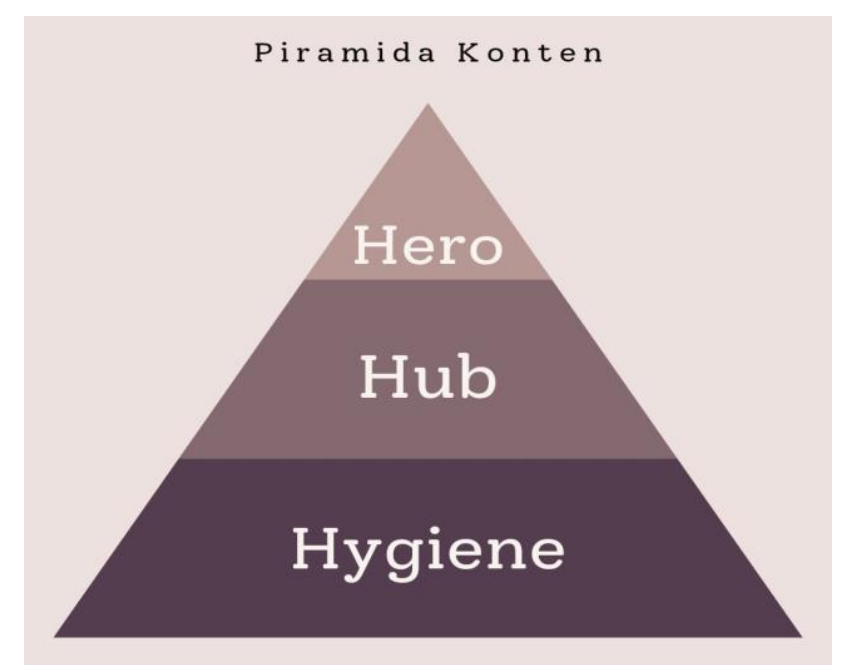

Gambar 1. Strategi Piramida Konten Petani Porang Milenial di Kabupaten Wonogiri

Hero sebagai konten utama, dimana konten ini isinya langsung berupa produk yang dijual atau hard selling, dalam hal ini konten dari akun media sosial yang dimiliki petani porang langsung berjualan produk hasil panennya yang akan dijual. Tujuannya untuk menyampaikan pesan utama dari pemasaran melalui media sosial yaitu untuk berjualan produk hasil panen porang petani. $\boldsymbol{H u b}$ sebagai konten penghubung, konten ini tidak langsung menjual produk hasil panen petani porang, akan tetapi berupa konten yang berisi hiburan yang berisi latar cerita dari porang dan/atau informasi seputar wilayah produksi dari petani porang ini. Tujuannya untuk memberi kesan baik kepada pelanggan, baik dari segi produk yang ditawarkan maupun dari konten yang disediakan. Hygiene sebagai konten rutin, dalam konten ini nanti berisi informasi mengenai gambaran umum terkait informasi atau berita harian dari perkembangan porang saat ini. Tujuannya untuk membantu memberi informasi seputar produksi dan budidaya produk mentah dari porang saat ini ataupun informasi lain yang bermanfaat kepada pengunjung media sosial untuk memperkenalkan produk secara umum.

Konten media sosial dari petani porang milenial di Kabupaten Wonogiri tersebut berupa desain gambar yang menarik dan dapat memikat mata pandang dari pengunjung. 
Prosiding Seminar Nasional Pembangunan dan Pendidikan Vokasi Pertanian

Politeknik Pembangunan Pertanian Manokwari, 31 Juli 2021

e ISSN : 2774-1982

DOI : https://doi.org/10.47687/snppvp.v2i1.175

Content marketing yang disusun dalam media sosial oleh para petani porang ini memuat tiga unsur utama diantaranya bermanfaat, relevan, dan konsisten. Apabila content marketing hanya bermanfaat tapi tidak relevan dengan produk porang dapat membuat pengunjung tidak nyaman dan merasa bingung, selain itu apabila sekedar bermanfaat dan relevan tetapi tidak konsisten maka akan mengakibatkan pengunjung sebagai pembeli akan merasa bosan. Oleh karena itu ketiga komponen tersebut saling berkorelasi dan ada dalam setiap konten yang akan disajikan dalam media sosial yang dikelola oleh petani porang milenial di Kabupaten Wonogiri. Menurut Pandrianto (2018) penggunaan konten dapat mendistribusikan pesan secara informatif yang artinya memberitahukan informasi yang mengenai pelaksanaan kegiatan dan produk, dengan kata lain informasi tersebut merupakan teaser yang mendorong rasa ingin tahu pengunjung untuk mengetahui lebih jauh konten berikutnya, sebagai pesan yang penuh akan dorongan (motivational appeal)

Selain itu strategi lain juga dilakukan oleh petani milenial di Kabupaten Wonogiri yaitu dengan membuka lelang online. Sistem lelang online yang dilakukan dengan menawarkan harga terlebih dahulu, sehingga para konsumen atau pengepul dapat mengikuti sistem lelang dengan saling tawar-menawar dan terdapat persaingan harga antara konsumen/pengepul yang lain. Waktu lelang biasanya dilakukan dalam jangka waktu 1x24 jam setelah sistem lelang dibuka. Penentuan hasil lelang diambil dari konsumen/pengepul yang menawarkan harga tertinggi namun, petani memastikan terlebih dahulu identitas dari konsumen atau pengepul yang terpilih. Proses selanjutnya yaitu deal antara petani dengan konsumen atau pengepul melalui pengambilan barang ke tempat petani dan melakukan pembayaran di tempat. Adapun konsumen atau pengepul di luar Kabupaten Wonogiri dapat dilakukan pembayaran melalui transfer bank dan pengiriman barang menggunakan jasa pengiriman. Pendapatan yang didapatkan oleh petani porang milenial di Kabupaten Wonogiri sebelum dan sesudah menggunakan media sosial jauh berbeda. Dimana, sebelum memakai media sosial penjualan hasil panen hanya terbatas pada konsumen atau pengepul lokal. Setelah adanya media sosial, penjualan hasil panen dari petani porang milenial di Kabupaten Wonogiri mampu menjangkau konsumen yang lebih luas, sehingga berdampak pada peningkatan pendapatan yang didapat.

\section{KESIMPULAN DAN SARAN}

Bentuk pemasaran digital yang digunakan oleh petani dalam pemasaran produk ini adalah penggunaan media sosial sebagai wadah dari pemasaran produk hasil panen tanaman porang di Kabupaten Wonogiri. Adanya penerapan media sosial di lingkup petani 
Prosiding Seminar Nasional Pembangunan dan Pendidikan Vokasi Pertanian

Politeknik Pembangunan Pertanian Manokwari, 31 Juli 2021

e ISSN : 2774-1982

DOI : https://doi.org/10.47687/snppvp.v2i1.175

milenial tidak hanya sebagai akses untuk memasarkan hasil panennya, tetapi juga digunakan untuk bertukar pengalaman atau berdiskusi dengan petani lainnya dengan grup yang dibuat. Supaya media sosial dapat menarik pengunjung dan selanjutnya dapat melakukan transaksi dengan petani porang milenial di Kabupaten Wonogiri diterapkan sebuah strategi content marketing dan juga pemasaran melalui kegiatan lelang online. Penerapan content marketing menggunakan sistem piramida konten yang terdiri dari 3 konsep yaitu Hero, Hub, dan Hygiene. Konten dan lelang yang diterapkan melalui media sosial berdampak nyata terhadap peningkatan penjualan hasil panen porang petani. Setelah adanya media sosial penjualan hasil panen dari petani porang milenial di Kabupaten Wonogiri mampu menjangkau konsumen yang lebih luas. Penggunaan media sosial oleh petani porang milenial di Kabupaten Wonogiri ini dengan mudah mempertemukan pembeli atau pengepul, sehingga lebih efektif dan efisien diterapkan dalam pemasaran terutama di masa pandemi COVID-19. Penelitian ini diharapkan dapat dijadikan contoh bagi para petani lainnya untuk menggunakan pemasaran digital berupa penggunaan media sosial dalam pemasaran hasil panennya, terlebih di masa pandemi supaya dapat mengurangi kontak fisik secara langsung. Strategi pemasaran yang tepat salah satunya dengan lelang online. Pemanfaatan media sosial sebagai pemasaran digital perlu diimbangi dengan design yang menarik dan konten yang terstruktur agar memikat konsumen/pengepul.

\section{DAFTAR PUSTAKA}

Anggia, M.N. \& Shihab, M R. (2018) Strategi Media Sosial Untuk Pengembangan Umkm. J Terapan Teknologi Informasi, 2(2), 159-170.

Arianto, B. (2020) Dampak Pandemi COVID-19 terhadap Perekonomian Dunia, J Ekonomi Perjuangan, 2(2), 106-126.

BPS Wonogiri. (2018) Data Statistik Pertanian Tanaman Pangan Kabupaten Wonogiri. [Online]. Tersedia di: https;//wonogirikab.bps.go.id.

BPS. (2018) Keadaan Ketenagakerjaan Indonesia Februari 2018. URL: https://www.turc.or.id/wp-content/uploads/2018/06/BPS_Berita-Resmi-

Statsitik_Keadaan-Ketenagakerjaan-Indonesia-Februari-2018.pdf. Diakses tanggal 6 Juli 2021.

BPS. (2021) Ekonomi Indonesia Triwulan I-2021 turun 0,74 persen (y-on-y). URL: https://www.bps.go.id/pressrelease/2021/05/05/1812/ekonomi-indonesiatriwulan-i-2021-turun-0-74-persen--y-on-y-.html. Diakses tanggal 7 Juli 2021.

Eddyono, S. et al. (2020) Pandemi dan yang Tersingkir: Menakar Urgensi Kebijakan Inklusif Penanganan Covid-19. Fakultas Ilmu Sosial dan Ilmu Politik UGM: UGM Press. 
Prosiding Seminar Nasional Pembangunan dan Pendidikan Vokasi Pertanian

Politeknik Pembangunan Pertanian Manokwari, 31 Juli 2021

e ISSN : 2774-1982

DOI : https://doi.org/10.47687/snppvp.v2i1.175

Feryanto, N.R. (2021) Penggunaan Telepon Seluler untuk Pemasaran Serta Dampaknya Terhadap Kesejahteraan Petani, J Agrisep, 20(1), 25-42.

Miles, M.B. \& Huberman, M.A. (2007) Analisis Data Kualitatif: Buku Sumber Tentang Metode-Metode Baru. Jakarta: UI Press.

Muljono, R.K. (2018) Pemasaran Digital Concept: Penggunaan Konsep Dasar pemasaran digital untuk Membuat Perubahan Besar. Jakarta: PT Gramedia Pustaka Utama

Nastiti, F.E. \& Abdu, A.R.N. (2020) Kajian: Kesiapan Pendidikan Indonesia menghadapi Era Society 5.0. J Kajian Teknologi Pendidikan Edcomtech, 5(1), 61-66.

Pandrianto, N., \& Sukendro, G.G. (2018) Analisis Strategi Pesan Content Marketing Untuk Mempertahankan, Brand Engagement. J Komunikasi, 10(2), 167-176.

Rofik, K., et al. (2017) Potensi Produksi Tanaman Porang (Amorphophallus Muelleri Blume) Di Kelompok Tani Mpsdh Wono Lestari Desa Padas Kecamatan Dagangan Kabupaten Madiun, J Ilmu Pertanian, Kehutanan dan Agroteknologi, 17(2), 5365.

Setiyorini, E.S., Noorachmat, B.P., \& Syamsun, M. (2018) Strategi Pemasaran Produk Olahan Hasil Perikanan pada UMKM Cindy Group, Jurnal Manajemen Pengembangan Industri Kecil Menengah, 13(1), 19-28.

Siagian, A.O., Rini, M., \& Natal, I. (2020) Kemajuan Pemasaran Produk dalam Memanfaatkan Media Sosial di Era Digital, Jurnal Pemasaran Kompetitif, 3(3), 44-51.

Sugiyono. (2013) Metode Penelitian Kuantitatif Kualitatif dan R \& D. Bandung: Alfabeta

Trymastuty, B., Hernanda, R.A., \& Firstya, E.D. (2020) Pemasaran Produk Hasil Pertanian Desa Pasuruhan Kecamatan Mertoyudan Melalui Media Sosial: Strategi Pendampingan Terstruktur. J Pengabdian Kepada Masyarakat, 1(1), 116-121.

WHO. (2021) WHO Coronavirus (COVID-19) Dashboard. URL: https://covid19.who.int/. Diakses tanggal 6 Juli 2021.

Wulandani, B.R.D. \& Anggraini, W. (2020) Food Estate sebagai Ketahanan Pangan di Tengah Pandemi COVID-19 di Desa Wanasaba, J Pengabdian Masyarakat Berkemajuan, 4(1), 386-390. 